\title{
The methodology for evaluation and predicting of clothing comfort for functional apparel
}

\author{
DOI: $10.35530 / I T .069 .03 .1316$
}

\section{Metodologia de evaluare și predicție a confortului îmbrăcămintei funcționale}

Scopul acestui studiu a fost testarea primului strat de îmbrăcăminte. Poate fi utilizat separat sau împreună cu alte straturi de textile în structura de tip sandwich a îmbrăcămintei. Deoarece acest strat intră în contact direct cu pielea, evaluarea nu se axează doar pe proprietățile sale termofiziologice, ci și pe percepția senzorială a țesăturii. Scopul principal al acestui strat este de a transporta căldură și umiditate de la piele către suprafață sau către celelalte straturi. O modalitate de a evalua confortul fiziologic al îmbrăcămintei este testarea articolelor de îmbrăcăminte în condiții și standarde de laborator. Pentru testare au fost alese tricouri din fibre naturale $100 \%$, fibre chimice și fibre mixte pentru comparație. Lucrările experimentale s-au desfășurat în următoarele două etape de testare în laborator: măsurarea proprietăților pentru confort fiziologic și gradul de măsurare a valorii totale a tușeului în sistemul de evaluare Kawabata. Pentru predicția confortului îmbrăcămintei și evaluarea rapidă a performanței îmbrăcămintei, a fost creată, de asemenea, o ecuație simplă pentru compararea setului selectat de tricouri.

Cuvinte-cheie: confortul îmbrăcămintei, evaluare obiectivă, îmbrăcăminte funcțională

\section{The methodology for evaluation and predicting of clothing comfort for functional apparel}

The aim of this study was testing the first layer of clothing. It can be used separately, or together with other layers of textiles in the sandwich structure of clothing. As this layer is in direct contact with the skin, the evaluation does not focus only on its thermo physiological properties, but also on sensory perception of the fabric. The main purpose of this layer is to transport heat and moisture from the skin to surface, or to the other layers. One way of assessing the physiological comfort of the garment is testing garments under defined conditions and standards in a laboratory. For testing, T-shirts made from 100 percent natural fibres, chemical fibres, and also mixed fibres for the comparison were chosen. Experimental work was carried out in the following two steps of laboratory testing: measurement of selected utility properties in the Laboratory of Physiological Comfort, and the measurement degree of Total Hand Value in the Kawabata Evaluation System. For the prediction of clothing comfort and the garment performance quick assessment, a simple equation for the comparison of the selected set of T-shirts was also created.

Keywords: clothing comfort, objective evaluation, functional apparel

\section{INTRODUCTION}

Sensorial comfort of clothing is a result of the interaction between the fabric and human skin sensory system and the atmospheric conditions [1]. Several studies have focused on sweating and heat loss of the wearer, since the amount of sweat and produce of heat reflects their physiological state [2-4]. The observation of the moisture distribution in clothing, its amount and location is also important for understanding the thermal stress and the thermal protection [5]. Moisture closed inside the structures of clothes can decrease the thermal protection of clothing and comfort of a wearer. It also influences other parts of clothing and it has a direct impact on subjective feelings and performance of wearers. The microclimate formed by human skin and the clothing reflects the interaction of a human, the environment and clothing. Our previous studies have been concentrated on the subjective evaluation of comfort perception by the human subject and the evaluation of the microclimate between the skin and the first layer of clothes according to the heat index WBGT standards [6]. The index
WBGT (Wet Bulb Globe Temperature) is a good indicator of the physiological safety of human subject under permanent load stress in the course of exercise [7]. This study deals with the first layer of clothing because it is the basic clothing layer which is in constant interaction with a wearer's skin. The prerequisite for achieving good clothing comfort is that this layer must not cause unpleasant sensory feeling when it is worn by the user. Our research has been primarily focused on selected objective methods, but we must consider the shape of clothing construction as well; therefore deal with a required fit and sequence of a clothing layer on human body surface [8-9]. The phenomenon of heat transfer under the sewing process has also influence on manufacturing clothes [10-11]. Clothing helps thermoregulation when the body itself is not capable of auto-regulation. "Comfort" can therefore be defined as the state of an organism when its physical functions are optimized and its environs, including clothing, do not produce any unpleasant sensations [12]. Heat transport depends on ambient temperature and a person's 
physical load. The most important material parameters, the thermal resistance $R_{c t}$, and the resistance to water vapour $R_{\text {et }}$ of the tested T-shirts were also evaluated in accordance with the EN ISO standard under standard conditions for testing textiles at $20^{\circ} \mathrm{C}$ and $65 \%$ of relative humidity on the skin model - SGHP 8.2 (Sweating Guarded Hot Plate) [13].

\section{MATERIALS AND METHODS}

The characteristics of the selected transport layer -1 st layer of clothing

The set of T-shirts for testing clothing comfort was selected based on the requirements for optimal physiological comfort both during normal activity and a medium weight job, especially in long term moderate loading of an organism during fitness training. The selected set of T-shirts covers a wide range of work apparel (for firefighters, maintenance, police, army, stewards, etc.) and is also suitable for sports activities. It is designed primarily for an environment without the possibility of easy replacement one piece of clothing by another, as it is common in professional sports activities. The first layer may serve as the outer layer of garment, or, as in our case, as the top layer of the garment. The table 1 shows the labelling of samples of clothing that have been selected for testing and their basic and selected material parameters measured relative to the investigated parameters.

\section{Transformation of determining characteristics}

The basic problem of the theory of utility properties is the transformation of variables of different physical significances and sizes to the commensurate variables of psychometric importance, as perceived by the user of the garment.

The user perceives the value of utility properties of fabrics only in a certain range (limits) and if the value falls below the limits of moral and physical endurance, the property is globally graded as unsatisfactory; if the value rises above the limits of the optimal perception, i.e. the user is not able to assess whether "it is better or worse", it will be generally evaluated as fully satisfactory [14].

The graph in figure 1 shows an example of evaluation when using the normalized index. This type of transformation is valid for determining the properties reaching mutually restricted optimum for determining

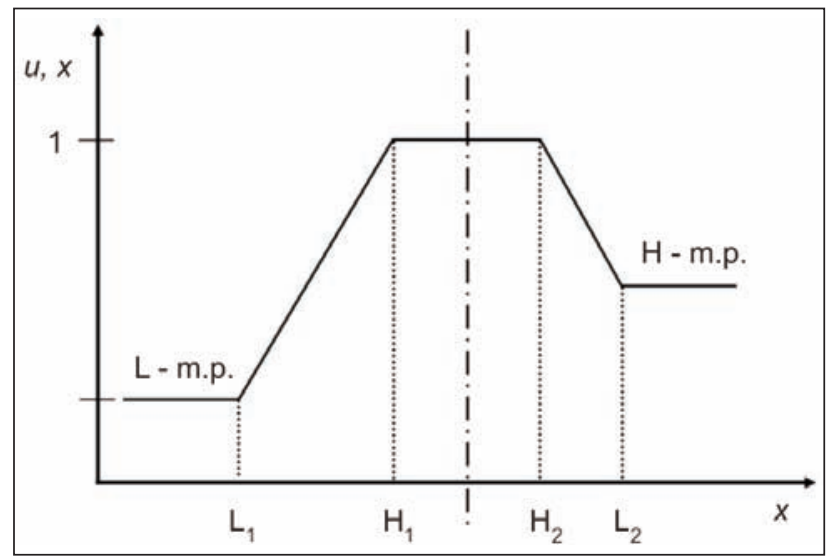

Fig. 1. Illustration of one or two-sided bonded transformation. $L_{1}, L_{2}$ - the lower limits, $H_{1}, H_{2}$ - the highest limits, L-m.p., H-m.p. - the high/low limit of usability of the product in terms of the properties of $x$ [14]

Table 1

THE BASIC PROPERTIES OF THE SELECTED SET OF T-SHIRTS

\begin{tabular}{|l|l|l|l|c|c|}
\hline Mark. & \multicolumn{1}{|c|}{ Material } & \multicolumn{1}{|c|}{ Origin } & \multicolumn{1}{|c|}{ Structure } & $\begin{array}{c}\text { Thickness } \\
{[\mathrm{mm}]}\end{array}$ & $\begin{array}{c}\text { Weight } \\
{\left[\mathbf{g} / \mathbf{m}^{2}\right]}\end{array}$ \\
\hline Ts1 & $100 \%$ CO & Czech Republic & weft single plain & 0.69 & 170 \\
\hline Ts2 & $100 \%$ WO (Merino) & Norway & weft double & 0.94 & 217 \\
\hline Ts3 & $100 \%$ PL & USA & weft interlock & 0.92 & 179 \\
\hline Ts4 & $100 \%$ CO & Bangladesh & weft single plain & 0.69 & 160 \\
\hline Ts5 & $100 \%$ WO (Merino) & Norway & weft single plain & 0.68 & 150 \\
\hline Ts6 & $100 \%$ CV & Czech Republic & weft interlock & 0.68 & 210 \\
\hline Ts7 & $96 \%$ WO (Merino)/ 4\% PADh & Czech Republic & weft single plain & 0.71 & 170 \\
\hline Ts8 & $100 \%$ PP & Czech Republic & weft double & 0.90 & 115 \\
\hline Ts9 & $\begin{array}{l}48 \% \text { WO/ 25\% PorexilThermocool/ } \\
\text { 25\% Tencel/ 2\% PADh }\end{array}$ & Czech Republic & weft double & 1.15 & 240 \\
\hline Ts10 & $100 \%$ Porexil Warm-light & Czech Republic & weft single plain & 0.88 & 178 \\
\hline Ts11 & $50 \%$ PorexilThermocool/ 50\% Tencel & Czech Republic & weft single plain & 0.79 & 167 \\
\hline Ts12 & $\begin{array}{l}35 \% \text { PorexilThermocool/ 35\% Tencel/ } \\
28 \% \text { PL VR micro/ } \% \% \text { PADh }\end{array}$ & Czech Republic & weft double & 0.93 & 182 \\
\hline Ts13 & $91 \%$ PL/ 9\% Antistatic fibre & Czech Republic & weft single plain & 1.52 & 210 \\
\hline Ts14 & $100 \%$ PP & Czech Republic & weft interlock & 1.51 & 189 \\
\hline Ts15 & $50 \%$ CO/ 50\% PL & Macedonia & weft single plain & 0.67 & 157 \\
\hline Ts16 & $100 \%$ PL & USA & weft single plain & 0.57 & 124 \\
\hline
\end{tabular}


the property. Determining the limits of determining features is a necessary step for the transformation into a commensurate quantity usable for the expression of the user's extent of perception by means of standardized utility properties. Resulting standardized utility property (normalized index of property) is a dimensionless value and may move in the interval $<0 ; 1>$. The above shown "stair function" represents a typical course of the dependence of standardized determining property on the value of utility property.

\section{EXPERIMENTAL WORK}

\section{Evaluation of total hand value in the Kawabata Evaluation System}

When examining a product by touch, hand value affects comfortable feelings of users. It is possible to assess user comfort with subjective or objective methods of measurement. All tested garments (T-shirts) of laboratory research have been the subject of an objective hand evaluation according to the Kawabata Evaluation System. The result is THV (Total Hand Value). THV is the World Standard of the Hand Evaluation guaranteed by The Hand Evaluation and Standardization Committee, The Textile Machinery Society of Japan. KES FB allows testing basic mechanical properties of fabrics [15].

This system uses four devices:

- KES FB1 for determination of tensile and shear characteristics of fabrics,

- KES FB2 for determination of bending characteristics of fabrics,

- KES FB3 for determination of compression characteristics of fabrics,

- KES FB4 for determination of surface characteristics.
Conditions of measurements on these machines were set with respect to specificity of measured fabrics. Deformations of tensile of knitted T-shirts were measured on the KES FB1 under mode with reduced standard tensile force. Surface characteristics of knitted T-shirts were measured on KES FB4 in mode of the adjustments of samples for reducing the elongation at clamping in the machine. The modified method can be considered comparative in the context of measurement and evaluation set of high strain knits. The evaluation was performed in Category KN-203LDY, KN-302-W. In this category, the primary properties are stiffness (Koshi), smoothness (Numeri), fullness and softness (Fukurami). The Total Hand Value (THV) is the zone of ratings from 1 to 5 , where the zone 1 is poor hand value and the zone 5 means excellent hand value. The results are presented in table 2.

\section{Evaluation of selected utility properties}

For material evaluation of T-shirts, the following parameters were chosen: thermal resistance $R_{c t}$ and resistance to water vapour $R_{\text {et }}$. Both of them have significant influence on the subject's physiological comfort feelings. These material parameters also reflect the ability of textile fabrics to keep the optimal clothing comfort. From the measured parameters, the index of water-vapour permeability (1) was accordingly calculated [13]:

$$
I_{m t}[-]=\left(R_{c t} / R_{e t}\right) \cdot S
$$

where:

$R_{\text {et }}$ is resistance against water-vapours $\left[\mathrm{m}^{2} \cdot \mathrm{Pa} \cdot \mathrm{W}^{-1}\right]$, $R_{c t}$ - thermal resistance $\left[\mathrm{m}^{2} . \mathrm{K} . \mathrm{W}^{-1}\right], \mathrm{S}$ equals 60 $[\mathrm{Pa} / \mathrm{K}]$.

THE MEASURED PARAMETERS AND CALCULATED RESULTS OF THE TESTED T-SHIRTS

\begin{tabular}{|c|c|c|c|c|c|}
\hline Mark. & $\mathbf{R}_{\mathbf{c t}}\left[\mathbf{m}^{\left.\mathbf{2} \cdot \mathbf{K} \cdot \mathbf{W}^{-1}\right]}\right.$ & $\mathbf{R}_{\mathbf{e t}}\left[\mathbf{m}^{\left.\mathbf{2} \cdot \mathbf{P a} \cdot \mathbf{W}^{-1}\right]}\right.$ & $\mathbf{I}_{\mathbf{m t}}[-]$ & THV $[$ Degree] & $\mathbf{I}_{\text {THV }}[-]$ \\
\hline Ts1 & 0.019 & 2.560 & 0.450 & 4.20 & 0.82 \\
\hline Ts2 & 0.037 & 2.590 & 0.860 & 4.31 & 0.84 \\
\hline Ts3 & 0.030 & 3.140 & 0.570 & 4.75 & 0.94 \\
\hline Ts4 & 0.025 & 2.786 & 0.550 & 5.04 & 1.00 \\
\hline Ts5 & 0.037 & 3.657 & 0.610 & 5.21 & 1.00 \\
\hline Ts6 & 0.026 & 3.125 & 0.500 & 3.60 & 0.69 \\
\hline Ts7 & 0.055 & 3.606 & 0.920 & 5.20 & 1.00 \\
\hline Ts8 & 0.028 & 2.550 & 0.650 & 3.30 & 0.62 \\
\hline Ts9 & 0.038 & 5.420 & 0.420 & 5.86 & 1.00 \\
\hline Ts10 & 0.034 & 3.840 & 0.530 & 4.10 & 0.80 \\
\hline Ts11 & 0.023 & 2.860 & 0.480 & 3.61 & 0.69 \\
\hline Ts12 & 0.024 & 3.610 & 0.390 & 4.52 & 0.89 \\
\hline Ts13 & 0.031 & 3.877 & 0.480 & 4.59 & 0.91 \\
\hline Ts14 & 0.046 & 5.120 & 0.540 & 4.58 & 0.91 \\
\hline Ts15 & 0.020 & 2.820 & 0.430 & 5.02 & 1.00 \\
\hline Ts16 & 0.026 & 3.125 & 0.500 & 3.41 & 0.64 \\
\hline
\end{tabular}


SPECIFICATION OF THE UTILITY QUALITIES AND COEFFICIENT OF SIGNIFICANCE FOR USE AS THE FIRST LAYER OF CLOTHING

\section{PARAMETERS of utility properties for textile clothing}

Way of Use: First layer of clothing - Overall direct contact with the human organism

\begin{tabular}{c|c|}
$\begin{array}{c}\text { Interval of } \\
\text { recommended } \\
\text { values }\end{array}$ & $\begin{array}{c}\text { Coefficient } \\
\text { of relevance }\end{array}$ \\
\hline
\end{tabular}

\begin{tabular}{|c|c|c|c|c|c|c|}
\hline & Determination of the utility qualities & Dimension & Measuring method & $\min$ & $\max$ & k \\
\hline 1 & Area weight & $\mathrm{g} / \mathrm{m}^{2}$ & ČSN EN ISO12127 & 80 & 120 & 0.981 \\
\hline 2 & Wet strength & $\mathrm{N}$ & ČSN EN ISO13934-1 & 100 & 300 & 0.932 \\
\hline 3 & Dry elongation & $\%$ & ČSN EN ISO13934-1 & 15 & 35 & 1.185 \\
\hline 4 & Abrasion-Accelerator-300s & $\%$ & ČSN 800833 & 5 & 8 & 0.852 \\
\hline 5 & Pilling & Etalon & ČSN EN ISO12945-2 & 3 & 5 & 1.006 \\
\hline 6 & Change of dimensions-5.washing & $\%$ & ČSN EN ISO 3077 & 1 & 3 & 1.466 \\
\hline 7 & Colour fastness & Etalon & ČSN EN ISO $105 \ldots . .$. & 3 & 5 & 1.275 \\
\hline 8 & Resistancetowater vapour- $R_{\text {et }}$ & $\mathrm{Pa} \cdot \mathrm{m}^{2} / \mathrm{W}$ & ČSN EN 31092 & 2 & 6 & 0.828 \\
\hline 9 & Heat-resistance- $\mathrm{R}_{\mathrm{ct}}$ & $\mathrm{m}^{2} \cdot \mathrm{K} / \mathrm{W}$ & ČSN EN 31092 & 0.02 & 0.04 & 0.826 \\
\hline 10 & Air Permeability & $\mathrm{mm} / \mathrm{s}$ & ČSN EN ISO 9237 & 100 & 400 & 0.792 \\
\hline 11 & Absorbency and capillary action & $\mathrm{mm}$ & ČSN 800828 & 30 & 80 & 1.438 \\
\hline 12 & $\begin{array}{l}\text { Moisture transport MMT } \\
\text { Unidirectional transport of moisture } \\
\text { Overall management of moisture } \\
\text { Moistening the ratio obverse/reverse }\end{array}$ & Degree & AATCC 195 & $\begin{array}{c}3.5 \\
3.5 \\
1\end{array}$ & $\begin{array}{c}5 \\
5 \\
>1\end{array}$ & 1.438 \\
\hline 13 & $\begin{array}{l}\text { Objectivehand evaluation(THV) } \\
\text { KAWABATASYSTEM }\end{array}$ & Degree & $\begin{array}{l}\text { IS KOD 01-2004 } \\
\text { (Internal Standard) }\end{array}$ & 3 & 5 & 0.980 \\
\hline
\end{tabular}

The resulting index value of water-vapour permeability, where $I_{m t}=0$ is the lowest limit, represents infinite resistance, while the resulting value 1 has a thermal resistance to water vapour, i.e. the same as an air layer of the same thickness [13].

Specifications of the utility qualities and determination of the coefficients of significance

For the first layer of the garment, very important qualities are to be able to convey a perception of wearing comfort to the user. These are determining utility qualities in the order of $8,9,10,11,12$, and 13 (table 3 ). Utility properties $2,3,4$ are carriers of durability characteristics of clothes. Properties 5, 6, 7 bring the wearers a feeling of good or bad product look. For the specification of parameters of utility properties in selected categories of use, the applicable standards DIN, EN and research work in the field of utility properties of fabrics $[14,16]$ were the basis.

\section{Evaluation of the experiment - suggesting an objective method for garment comfort evaluation}

For the purpose of garment performance quick, objective and comparative assessment, and the physiological comfort which provides clothing tested for a long-term physical activity of users, comfort index $I_{\text {com }}$ was designed. The evaluation is based on three objectively measured parameters of textiles, which affect the user's overall feeling of comfort.
Clothing comfort index is calculated by the following equation (2):

$$
I_{\text {com }}[-]=k_{1} \cdot I_{m t}+k_{2} \cdot I_{T H V}
$$

where:

$k_{1}, k_{2}$ - constant of significance [-], $I_{m t}-$ water-vapour permeability index [-], $I_{T H V}-$ index of sensorial feeling from a textile $[-]$.

Selected parts of the comfort index are an important component for the evaluation of thermo-physiological comfort and sensorial feeling from a textile and allow us to evaluate qualitatively a garment made therefrom. For determining a scale of coefficient of significance $k_{1}$ and $k_{2}$, it is possible and recommended to take the values listed in the table 3 . In this case $k_{1}=0.83, k_{2}=0.98$.

\section{RESULTS AND DISCUSSION}

The first layer of clothing can be used separately, or together with other layers of textiles in the sandwich structure of clothing. The functional basis of this garment structure is the first layer which removes perspiration and vapour from the skin surface into next layers and therefore this function is primarily focused on this layer of garment. In the final table, table 4, there are individual T-shirts put in order based on the highest index achieved by multi-criteria assessment according to $I_{\text {com }}$. The higher number, the better chances of achieving optimum physiological properties during long-term load. 
THE OVERALL INDEX OF COMFORT CALCULATED FOR THE EXAMINED SET OF TEXTILE

\begin{tabular}{|c|c|c|c|c|c|c|c|c|c|c|c|c|c|c|c|c|}
\hline Order & 1. & 2. & 3. & 4. & 5. & 6. & 7. & 8. & 9. & 10. & 11. & 12. & 13. & 14. & 15. & 16. \\
\hline Mark. & Ts7 & Ts2 & Ts5 & Ts4 & Ts3 & Ts14 & Ts15 & Ts9 & Ts13 & Ts10 & Ts12 & Ts1 & Ts8 & Ts6 & Ts11 & Ts16 \\
\hline $\mathrm{I}_{\text {com }}[-]$ & 1.74 & 1.54 & 1.49 & 1.44 & 1.39 & 1.34 & 1.34 & 1.33 & 1.29 & 1.22 & 1.20 & 1.18 & 1.15 & 1.09 & 1.07 & 1.04 \\
\hline
\end{tabular}

The obtained results from the research are included in table 2 and table 4 . From the results of THV from the Kawabata system we can conclude that all of the tested T-shirts obtained good and very good rating, with the best result being obtained by the T-shirts No. $9,5,4,15$. From the resulting index of water-vapour permeability, the best rating obtained T-shirts No. 7, 2 made from merino wool. According the multi-criteria index of comfort clothing $I_{\text {com }}$, it can be concluded that T-shirt No. 7 (96.33\%), T-shirt No. 2 (84.92\%), T-shirt No. 5 (82.12\%), which are made from merino wool, obtained optimal results.

\section{CONCLUSIONS}

This article is primarily focused on the possibility of objective evaluationand comparison of the sensorial feelings of knit fabrics in the Kawabata Evaluation System. The first layer of clothing is in direct contact/interaction with human skin and its basic function is to transfer moisture and heat to reach and maintain the wearer's physiological, thermo-physiological and sensorial feeling of comfort. Reaching these comfort zones is crucial for the overall comfort of the wearer. The experiment was focused on objective methodology for evaluating and predicting clothing comfort for functional apparel using the index of clothing comfort. The multi-criteria index proposal which includes all the aspects mentioned above was developed to evaluate physiological comfort and it allows a quick comparison of a set of T-shirts. The methodology is based on objectively measured data and the basic formula may be easily extended by additional parts such as the index WBGT (Wet Bulb Globe Temperature), MMT test, air permeability, etc. The basic equation consists of thermo-physiological properties and sensorial characteristic of knit fabrics, represented by the THV index and the index of watervapour permeability. The clothing comfort index proposal can be used for quick assessment of garment performance mainly designed for recreational sportsmen, with no other special requirements for clothing and with the possibility of a piece of clothing to be easily replaced by another. On the contrary, if there are special requirements for the garment, it is appropriate to extend the equation by further evaluation criteria. T-shirts made from merino wool obtained the best result, but certain sensitive people could feel discomfort when wearing T-shirts made from natural merino wool. From the above mentioned results it is clear that the choice of a suitable first layer of clothing is complicated and it will be a compromise (mix) between different properties and preferences of wearers. Therefore, it is always necessary to choose a T-shirt according to its intended use. Moreover, other conditions must be taken into account as well, such as the expected length of wearing, physical activity, weather conditions etc.

\section{ACKNOWLEDGEMENT}

This work was supported by the Ministry of Education, Youth and Sports of the Czech Republic and the European Union - European Structural and Investment Funds in the frames of Operational Programme Research, Development and Education - project Hybrid Materials for Hierarchical Structures (HyHi, Reg. No. CZ.02.1.01/0.0/0.0/16_019/ 0000843).

\section{BIBLIOGRAPHY}

[1] Das, A., Alagirusamy, R. Improving tactile comfort in fabrics and clothing. In: Song G. (ed.) Improving Comfort in Clothing, 1st ed. Oxford. Philadelphia: Woodhead Publishing, 2011.

[2] Yoo, S., Kim, E. Wear trial assessment of layer structure effects on vapor permeability and condensation in a cold weather clothing ensemble. In: Textile Research Journal, 2012; 82(11), pp. 1079-1091. Available from: doi:10.1177/ 0040517512438123. [Accessed 3th February 2016].

[3] Nemcokova, R., Glombikova, V., Komarkova, P. Study on liquid moisture transport of knitted fabrics by means of Mmt, Thermography and Microtomography Systems. In: AUTEX Research Journal, Lodz; 2015; 15(4), pp. $233-242$. Available from: doi: 10.1515/aut-2015-0022. [Accessed 3th February 2016].

[4] Havelka, A., Glombikova, V., Kus, Z., Chotebor, M. The thermal insulation properties of hightech sportswear fillings. In: International Journal of Clothing Science and Technology, 2015; 27(4), pp. 549-560. Available from: http://www.emeraldinsight.com/doi/10.1108/IJCST-03-2014-0038. [Accessed 9th February 2016].

[5] Lee, M.L., Barker, R.L. Effect of moisture on the thermal protective performance of heat-resistant fabrics. In: Journal of Fire Science, 1986; vol. 4(5), pp. 315-331. Available from: doi: 10.1177/073490418600400502. [Accessed 3th February 2016]. 
[6] Nagy, L., Havelka, A., Jandova, S., Kus, Z. Physiological comfort in garments for sport activities and its testing. In: Luo Q. (ed.) Sports Technology and Engineering: Proceedings of the 2014 Asia-Pacific Congress on Sports Technology and Engineering. London: CRC Press; 2015. pp. 347-351.

[7] ČSN ENISO 7243:1989 Hot environments. Estimation of the heat stress on working man, based on the WBGTindex (wet bulb globe temperature). $2^{\text {nd }}$ ed. Praha: Unmz, 1993.

[8] Musilova, B., Komarkova, P., Kus, Z. Project on assessment methods of constructional allowances for looseness of clothing. In: Fibres and Textiles, 2003; 2, pp. 18-22.

[9] Komarkova, P., Glombikova, V. The effect of anatomical changes in the female body during pregnancy on pattern designs for maternity wear. In: Tekstilve Konfeksiyon, Izmir; 2013; 23(4), pp. 409-415.

[10] Mazari, A., Havelka, A., Wiener, J. and Zbigniew, R. A study on DLC-coated industrial lockstitch sewing needle. In: Industria Textila, 2015; 66(1), pp. 43-47.

[11] Mazari, A., Zhu, G., Havelka, A. Sewing needle temperature of an industrial lockstitch machine. In: Industria Textila, 2014; 65(6), pp. 335-339.

[12] Hes, L., Sluka, P. Introduction to the comfort of textiles. 1st ed. Liberec: Technical University of Liberec; 2005.

[13] ISO 11092: Textiles - Physiological effects - Measurement of thermal and water-vapour resistance under steadystate conditions (Sweating Guarded Hotplate Test). 2nd ed. Praha: ČNI; 2014.

[14] Švehla, K., Kašparová, M. Utility qualities of fabrics. SVUT. Liberec; 1976.

[15] Kolinova, M., Koldinska, M. Sensory evaluation of comfort for functional knitted fabrics. In: Fine Mechanics and Optics, 2015; 60(8), pp. 296-298.

[16] Křemenáková, D. Fibrous structure for special applications. In: 1st ed. Militký J, Šesták J. (eds.) Kanina: OPS; 2013. vi, $334 \mathrm{p}$.

Authors:

\author{
Ing. LADISLAV NAGY, Ph.D. ${ }^{1}$ \\ Ing. MARIE KOLDINSKÁ ${ }^{1}$ \\ doc. Ing. ANTONÍN HAVELKA, CSc. ${ }^{1}$ \\ doc. PhDr. SOŇA JANDOVÁ, Ph.D. ${ }^{2}$
}

${ }^{1}$ Technical University of Liberec, Faculty of Textile Engineering, Department of Clothing Technology Studentska 2, Liberec, 461 17, Czech Republic

${ }^{2}$ Technical University of Liberec, Faculty of Mechanical Engineering, Department of Applied Mechanics Studentska 2, Liberec, 461 17, Czech Republic

Corresponding author:

LADISLAV NAGY

e-mail: ladislav.nagy@tul.cz 